\title{
Token and Taboo: Behavior Modification, Token Economies, and the Law
}

\author{
David B. Wexler*
}

Not surprisingly, legal concepts from the prisoners' rights movement have begun to spill over into the area of the rights of the institutionalized inentally ill. Simce the mental patient movement is free of the law and order backlash that restrains the legal battles of prisoners, it may evoke considerable sympathy from the public, the legislatures, and the courts.

Commentators and authorities have recently directed attention to important procedural problems in the administration of psychiatric justice $^{1}$ and to the legal issues presented by various methods of therapy. Legal restrictions on a hospital's right to subject unwilling patients to electroconvulsive therapy ${ }^{2}$ and psychosurgery $^{3}$ are developing rapidly, and close scrutiny is now being given to "aversive" techniques of beliavior inodification and control ${ }^{4}$ - such as procedures for suppressing transvestitisin by administering painful electric shocks to the patient while dressed in wounen's clothing, and procedures for controlling al-

* Professor of Law, University of Arizona. B.A., 1961, Harpur College; J.D., 1964, New York University.

1. See, e.g., Wexler, Scoville et al, The Administration of Psychiatric Justice: Theory and Practice in Arizona, 13 ARIz. L. REv. 1 (1971) [hereinafter cited as Psychiatric Justice ProJect].

2. N.Y. Times, July 15,1972 , at 7 , col. 3. In California, section $5325(f)$ of the Welfare and Institutions Code gives a patient the right to refuse shock treatment, but the following section allows the professional person in charge of the institution, or his designee, to deny the right "for good cause." CAL. WelF. \& INST'NS CODE § 5326 (West Supp. 1971).

3. Breggin, The Return of Lobotomy and Psychosurgery, 118 CoNG. REc. E1602 (daily ed. Feb. 24, 1972). Possible neurological bases of deviant and violent behavior are discussed in V. Mark \& F. ERvin, Violence and The Brain (1970). Sociolegal inplications of the Mark \& Ervin work are explored in Wexler, Book Review, 85 HARv. L. Rev. 1489 (1972).

4. R. Schwitzgebel, Development and Legal Regulation of Coercive Behavior Modification TechNiques WITH Offenders (1971). Schwitzgebel's work has been condensed to article form in Scliwitzgebel, Limitations on the Coercive Treatment of Offenders, 8 CRIM. L. BuLL. 267 (1972). On aversion therapy generally, see S. Rachman \& J. Teasdale, Aversion Therapy and Behavior Disorders (1969); A. Bandura, Principles of Behavior Modification 293-354 (1969) thereinafter cited as BANDURA]. 
coholism or narcotics addiction by arranging medically for severe nausea or even teinporary paralysis (including respiratory arrest) to follow ingestion of the habituating substance..$^{\prime \prime}$ It is likely that certain treatments may be deeined so offensive, frightening, or risky that the law may eventually preclude them altogether, ${ }^{6}$ or at least restrict thein by requiring the patient's informed consent. ${ }^{7}$

Though aversive therapeutic techniques are receiving close attention, scheines of "positive" behavior control" - whereby appropriate, non-deviant behavioral responses are encouraged by rewarding their occurrence-have not been subjected to any careful study. It is perhaps assumed that when rewards rather than punishments are einployed, no grave legal, social or ethical questions are involved. ${ }^{0}$ To a great extent, that is unquestionably true: few would have their ire aroused, for example, by praising a child and offering him candy for correctly spelling or reading a word, ${ }^{10}$ nor would many be upset over a scheine that encouraged scholastic achievenient of institutionalized juvenile delinquents by offering them, contingent upon academic success, private rooms, a wider choice of food, and selections of iteins froin a mail-order catalogue. ${ }^{11}$ But, as will be seen in the following section, inany techmiques of positive control are far inore troubling. Most troubling of all seem to be the use of token economies with chromic psychotic inental patients.

5. See Schwitzgebel, Limitations on the Coercive Treatment of Offenders, 8 CRIM. L. BuLl. 267, 285-86 (1972). Anectine, a drug that induces temporary paralysis and respiratory arrest, has been used for behavior control in sone California institutions. See Note, Conditioning and Other Technologies Used to "Treat?" "Rehabilitate?" "Demolish?" Prisoners and Mental Patients, 45 So. Calif. L. Rev. 616, 633.40 (1972).

6. Dr. Peter Breggin argues that psychosurgery should be precluded on these grounds. See generally Breggin, supra note 3.

7. "Patients have a right not to be subjected to treatinent procedures such as lobotomy, electro-convulsive treatment, adversive [sic] reinforcement conditioning or other unusual or hazardous treatment procedures without their express and informed consent after consultation with counsel or interested party of the patient's choice", Wyatt v. Stickney, 344 F. Supp. 373, 380 (M.D. Ala. 1972), (dealing with Bryce and Searcy Hospitals for the mentally ill). See also Wyatt v. Stickney, 344 F. Supp. 387, 400 (M.D. Ala. 1972), (dealing with Partlow State School and Hospital for the mentally retarded). These two cases will hereinafter be distinguished by bracketed indication of the hospital they dealt with.

8. BANDURA, supra note 4, at 217-92.

9. Cf. McIntire, Spare the Rod, Use Behavior Mod, Psychology Today, Dec. 1970 , at 42 . Considerable controversy is, of course, generated by calls for behavioral engineering on a society-wide scale, such as is advocated in B.F. SkINNER, Beyond FreEdom AND Dignity (1971). See, e.g., Ramsey, Book Review, 7 Issues IN CRIM. 131 (1972) (reviewing Skinner's book).

10. Cf. BANDURA, supra note 4 , at $249-50$ (positive reinforceinent as a technique for improving reading skills).

11. Cf. Bandura 278-79. 


\section{Psychology and TOKEN ECONOMIES}

\section{A. General Considerations}

Many behavior modification practitioners apply clinically the learning theory principles of Skinnerian operant conditioning. Operant theory is bottomed on the principle, amply demonstrated by empirical data, that behavior is strengthened or weakened by its consequences. ${ }^{12}$ The frequency of a behavior increases if it is followed by desirable consequences, whereas it will be extinguished if the positive consequences are discontinued or if the consequences are aversive. ${ }^{13}$

The application of operant conditioning to humans has come a long way since 1949 , when a severely regressed person was taught to raise his arm by a procedure that rewarded appropriate arm motions by the subsequent squirting of a sugar-milk solution mto his mouth. ${ }^{14}$ Now, a multitude of therapeutic behavior modification systems are in operation on ward-wide and institution-wide scales. By and large, these programs seek to shape ${ }^{15}$ and maintain appropriate behavior patterns-desiguated as "target behaviors" or "target responses"-by rewarding or "reinforcing" the desired responses. Usually, rewards are dispensed in the form of tokens or points-known as "secondary" or "generalized" reinforcers-which can then be converted, pursuant to a specific economic schedule, to "primary reinforcers" such as snacks, inail-order catalogue items, and the like.

12. A good introductory text on operant conditioning is J. R. Mulensson, Principles of Behavioral Analysis (1967). Chapters Two and Three deal with Classical or Pavlovian Conditioning, which is to be distinguished from operant conditioning; the latter provides the basis of the token economy. See also Note, 45 So. CALIF. L. Rev. 616, 627-28 (1972).

13. Note that the behavioral psychologist explains both normal and abnormal behavior by the same principles, in an approach which differs fundamentally from "dynamic" psychology, of which the Freudian system of psychoanalysis is probably the most familiar to laymen. The dynamic psychologists, who follow a "medical model," explain abnormal behavior as the product of "mner conflicts" and the like. For a good introduction to behavior modification and how it contrasts with traditional dynamic concepts, see L. Ullmann \& L. Krasner, Case Studies In Behavior Modification 1-65 (1965). See also Bandura 1-69. For more recent accounts of the application of behavioral psychology to clinical settings, see any recent issue of the JOURNAL OF APpLIED BEHAVIOR ANALYSIS.

Technically, the tern extinction is reserved for the process of reducing the frequency of a behavior by discontinuing the "reinforcing" [rewarding] consequences.

14. Fuller, Operant Conditioning of a Vegetative Human Organism, 62 AM. J. Psychology 587 (1949). For somewhat more recent studies, see UlLMaNN \& KrasNER, supra note 13, and R. UlrRich, T STACHNIK, J. MABRY, Control of HuMaN BEHAVIOR (1966).

15. "Shape" is a technical term used by operant psychologists to describe the process of gradually building a new behavior by rewarding closer and closer approximations to it. 
These "token economies" have flourished since their development in the sixties ${ }^{16}$ and are currently einployed in a variety of clinical settings. ${ }^{17}$ This Article will be confined almost exclusively to a discussion of the application of the token system to chronic psychotics.

There are two reasons for this limitation in scope: first, despite mammoth advances in psychopharmacology ${ }^{18}$ and a burgeoning cominunity psychiatry movement ${ }^{19}$ which have combined to reduce drastically inental hospital enrollment, almost all chronic psychotics are still hospitalized. ${ }^{20}$ If other clinical categories are increasimgly diverted from institutions while the chromics continue to accumulate, the treatment of the chronic psychotic may soon constitute the major therapeutic concern of mental hospitals. Second, because the behavior patterns of chronic psychotics are by defimition particularly resistant to therapy, more drastic nrethods of behavior modification have been applied to them. These therapeutic methods will raise important legal questions.

\section{B. Token Economies}

Teodoro Ayllon and Nathan Azrin pioneered the token economy concept on a ward of chronically psychotic female patients at the Anna State Hospital in Illinois. ${ }^{21}$ Because of their adaptation to long periods of stagnant hospitalization, chronic patients typically suffer from

16. Ayllon \& Azrin, The Measurement and Reinforcement of Behavior of Psychotics, 8 J. OF THE EXPERIMENTAL ANALYSIS of BeHAVIor 357 (1965); T. AYLloN \& N. AzRin, The TOKen Economy: a Motivational. System For Therapy ANd REhabilitation (1968) [hereinafter cited as Token Economy] (report of a project begun in 1961). In part, the flourishing is no doubt due to the fact that much behavior therapy can be conducted by psychiatric nurses, attendants, and paraprofessional personnel. See Ayllon \& Michael, The Psychiatric Nurse as a Behavioral Engineer, 2 J. of tHe EXPERIMENTAL ANALYSIS of BeHAvior 323 (1959). The rationale behind emphasizing the development of constructive behavior rather than emphasizing the elimination per se of so-called "pathological" behavior appears to be that pathological traits in an otherwise well-functioning individual may well be dismissed as mere idiosyncracies, and, inoreover, that pathological traits may not be able to coexist with functional behavior. TOKEN ECONOMY 23.

17. These include populations of juvenile delinquents, newly admitted and chronic psychotics, mentally retarded patients, etc. ToKen Economx 217. For various descriptions, see BANDURA 261-82; Davison, Appraisal of Behavior Modification Techniques with Adults in Institutional Settings, in BeHavior TherapY: APPRAISAL aND STatus 250 (C. Franks ed. 1969); Krasner, Token Economy As an Illustration of Operant Conditioning Procedures with the Aged, with Youth, and with Society, in Learning Approaches to Therapeutic Behavior Change 74 (D. Levis ed. 1970). See generally Kazdin \& Bootzin, The Token Economy: An Evaluative Review, 5 J. of Applied Behavior ANajysis 343 (1972).

18. Jarvik, The Psychopharmacological Revolution, in REAdINGS IN CLINICAL PSYCHOLOGY TODAY 93 (1970).

19. Psychiatric JUSTICe PRoject, supra note 1, at 118-27.

20. E.g., Bruce, Tokens for Recovery, 66 AM. J. NuRsing 1799 (1966).

21. TOKEN ECONOMX, supra note 16. 
extreme apathy and dependency. This condition, known as institutionalization, ${ }^{22}$ impedes the chronic's chances for improvement or release. To overcome this problem, Ayllon and Azrin rewarded target behaviors that would reverse the institutionalization syndrome. Work assignments within the hospital and various self-care behaviors were rewarded with tokens. The self-care category included grooming, bathing, toothbrushing, bed making and the like. ${ }^{23}$ Work assignments included kitchen chores, serving in the dining room, assisting in the laundry, janitorial work, and related tasks. ${ }^{24}$

For the token economy to succeed, it is necessary to insure that the items or events purchasable with the tokens are effective reinforcers -in lay terms, that they would in fact be desired by the patients. To solve this problem, the Anna State Hospital psychologists applied the "Preniack Principle":25 if certain behaviors occur naturally with a high frequency, then the opportunity to engage in those behaviors can be used as an effective reinforcer to strengthen a low-frequency behavior. The psychologists determined the high frequency-behaviors empirically:

It was noted that certain patients often hoarded various items under their mattresses. The activity im this case, in a general sense, consisted of concealing private property in such a manner that it would be inaccessible to other patients and the staff. Since this event seemed to be highly probable, it was formally scheduled as a reinforcer. Keys to a locked cabinet in which they could conceal their private possessions just as they had been doing with the mattresses were made available to patients.

Another activity that was observed to be highly probable was the attempt of patients to conceal themselves in several locations on the ward in an effort to enjoy some degree of privacy. A procedure was therefore instituted whereby a patient could obtain a portable screen to put in front of her bed or access to a bedroom with a door. Another event that had a high probability of occurrence for some patients was a visit with the social worker or psychologist. This was used as a reinforcer by arranging appointments with either of these staff members. ${ }^{20}$

22. See generally E. GoffMan, Asylums (Anchor ed. 1961). See also PsYChiAtric Justice Project 237-38: "The depressing surroundings, the idleness, the loss of ordinary privileges, the isolation from family, friends and developments in the outside world-these and many other aspects of institutional life, which are almost inherent characteristics of state hospitals, lead to a loss of motivation, to withdrawal and regression, and to apathy, submissiveness and an inability to make decisions. In short, hospitalization itself produces a distinct functional pathology, appropriately dubbed "institutional neurosis." " (citations omitted).

23. TOKEN ECONOMY, supra note 16, at 250.

24. Id. at 134-35.

25. Id. at 60. See Premack, Toward Empirical Behavior Laws: I. Positive Reinforcement, 66 PsychologicaI Rev. 219 (1959).

26. TOKEN ECONOMY 61. 
Ground privileges and supervised walks by the staff were also established as reinforcers by application of the Premack Principle, since patients were frequently observed to "stay at the exit to the ward and try to leave."27 The opportunity to attend religious services was also used as a reinforcer since several patients attended frequently when they were allowed to freely. ${ }^{28}$

Thus, personal cabinets, room dividers, visits with the professional staff, ground privileges, supervised walks, and religious services were all made contingently available to the patients: they could be purchased if the patient had performed a sufficient number of target responses to have earned the requisite tokens to purchase the reinforcers. They were otherwise unavailable. Other reinforcers in the Anna State Hospital program imcluded a personal chair, writing materials and stationery, movies, television programs, and various commissary items. ${ }^{20}$

By using these "strong, albeit untapped"30 sources of motivation, the Ayllon and Azrin economy produced rather impressive results when measured by, standards of work performance. They compared the work output of their patients during a specified period of the token econoniy with a subsequent experimental period during which the various reinforcers were freely available without tokens-a situation which "approximated the usual conduct of a mental hospital ward." ${ }^{31}$ Ayllon and Azrim found that patient performance during the experimental period plummeted to less than one-fourth the token economy level. Hence, they concluded that "the performance on a usual ward would be increased fourfold by instituting this motivating environment."32

Nonetheless, the Anna State Hospital program did not change the behavior of 8 out of the 44 patients $^{33}$ involved:

Eight patients, who expended fewer than 50 tokens within 20 days, all earned by self-care rather than from job assigninents, were relatively unaffected by the reinforcement procedure. Statistical comparison of them with the other patients revealed no difference in diagnosis or age. It appears that their failure to modify behavior appreciably stemmed from the relative absence of any strong behavior patterns that could be used as reinforcers. The only two behaviors that existed in strength were sleeping and eating. The present program did not attempt to control the availability of food.

27. Id. at 221. See also id. at 64-65.

28. Id. at 62-63.

29. Id. at 226.

30. Id. at 269 .

31. Id. at 188.

32. Id. See also id. at 256-61.

33. Id. at 239. 
This action may have to be considered in future research in order to rehabilitate patients with such an extreme loss of behavior. ${ }^{34}$

Many token economy programs have been patterned after the Ayllon and Azrin model. ${ }^{35}$ In Atthowe's program for chronic patients at the Palo Alto Veterans Administration Hospital, for example, patients earned points not only for their industrial therapy job assignments, but also for participating in group activities, in recreational therapy, and for attending weekend movies. ${ }^{36}$ And reinforcers in various programs include later wake-up times, ${ }^{37}$ passes, ${ }^{38}$ clothing, ${ }^{39}$ clothing maintenance, ${ }^{40}$ reading inaterials, ${ }^{41}$ dances, ${ }^{42}$ and even release. ${ }^{43}$ Moreover, several programs have taken the step recommended but not taken by Ayllon and Azrin and have made food and beds available only on a contingent basis. ${ }^{44}$ Indeed, those prograins have exceeded the Ayllon and Azrin recommendation by using beds and meals as reinforcers on a ward-wide basis, and thus even for patients who have not failed under a system where food and sleeping facilities were noncontingently available.

One of the token economies that hinges food and beds on appropriate behavioral responses-a chronic ward at the Patton State Hospital in San Bernardino, California-is "willing to let a patient go for as long as five days without food, or until he has been reduced to $80 \%$

34. Id. at 269. But see the remarks of Davison directed at Ayllon \& Azrin's conclusion: "I believe that Ayllon and Azrin would do well to break set and at least consider the possibility that the beliavior (both overt and covert) of some chronic hospital patients is regulated by processes which have little, if anything, to do with operant conditioning." Davison, supra note 17 , at 250.

35. E.g., Atthowe \& Krasner, Preliminary Report on the Application of Contingent Reinforcement Procedures (Token Economy) on a "Chronic" Psychiatric Ward, 73 J. AbNoRmal Psychology 37 (1968).

36. Atthowe, Ward 113 Program: Incentives and Costs-A Manual for Patients 7-8 (Veterans Ad., Palo Alto, Calif., Oct. 1, 1964).

37. Id. at 4. The present author also visited a token economy where naps were available for five tokens per hour.

38. Id. at 5 .

39. Lloyd \& Abel, Performance on a Token Economy Psychiatric Ward: A Two Year Summary, 8 Behav. Res. \& TherApy 1, 6 (1970).

40. Narrol, Experimental Application of Reinforcement Principles to the Analysis and Treatment of Hospitalized Alcoholics, 28 Q. J. OF STUDIes on AlcoHol 105, 108 (1967).

41. Gripp \& Magaro, A Token Economy Program Evaluation with Untreated Control Ward Comparisons, 9 BeHAv. Res. \& TherApY 137, 141 (1971).

42. Id.

43. Glicksinan, Ottomanelli \& Cutler, The Earn-Your-Way Credit System: Use of a Token Economy in Narcotic Rehabilitation, 6 INT'x. J. OF THE ADDICTIONS 525 (1971). Cf. Lloyd \& Abel, supra note 39, at 5.

44. E.g., Schaefer, Investigations in Operant Conditioning Procedures in a Mental Hospital, in Reinforcement Theory In Psychological Treatment-A Symposium 25, 26 (J. Fisher \& R. Harris eds. 1966) (Calif. Ment. Health Res. Monog. No. 8); Bruce, Tokens for Recovery, 66 AM. J. NuRsIng 1799, 1801 (1966); Gripp \& Magaro, supra note 41, at 141; Lloyd \& Abel, supra note 39 at 6. 
of his previous body weight." 45 The Patton program is one of several token economies" ${ }^{46}$ that follows a "phase" or "tier" system, where at least certain privileges are dependent upon the patient's place in the hierarchy of tiers.

At Patton, for example, newly admitted patients are placed in the orientation group, where living conditions are exceedingly drab, and where the subsistence-level existence can be purchased for a small number of tokens. After a patient has adapted well to the orientation group, he is elevated to the middle group, where conditions are better but are considerably more expensive. Patients in the middle group are given five months to be promoted to the rather luxurious ready-toleave group, but if after three months in the middle group a patient is not adequately facing the eventual prospect of life on the outside, he will be returned to the orientation group. ${ }^{47}$ Margaret Bruce, a psychiatric technician at the Patton State Hospital, described the orientation group in these words:

This group sleeps in a relatively unattractive dormitory which conforms to bare minimums set by the state departunent of mental hygiene. There are no draperies at the windows or spreads on the beds, and the beds themselves are of the simplest kind. In the dining room the patient sits with many other patients at a long table, crowded in somewhat uncomfortably. The only eating utensil given him is a large spoon. The food is served in unattractive, sectioned plastic dishes. So long as he is in this group, he is not allowed to wear his own clothes and cannot go to activities which other patients are free to attend off the unit. He nay not have permission for off-the-ground visits, and the number of visitors who can see him is restricted.

During this time, the patient learns that his ineals, his bed, his toilet articles, and his clothes no longer are freely given him. He unust pay for these with tokens. These tokens pay for all those things normally furnished and often taken for granted. In the orientation group most of the things the patient wants are cheap; for example, it costs one token to be permitted to go to bed, one token for a meal. Patients find it easy enough to earn the few tokens necessary for bare subsistence. ${ }^{48}$

45. Schaefer, supra note 44, at 33-34. Actually, the quoted remark was made in the context of overcoming refusal-to-eat problems exhibited by some of the patients, but if the hospital is medically willing to allow those patients to miss five consecutive days of meals, it seems reasonable to assume that the same medical standard would be apphed to patients who presumably desire to eat but who have not earned a sufficient number of tokens to pay for meals.

46. E.g., Lloyd \& Abel, supra note 39; Narrol, supra note 39. Cf. Atthowe \& Krasner, supra note 35.

47. Bruce, Tokens for Recovery, 66 AM. J. Nursing 1799, 1802 (1966).

48. Id. at 1800-01. The Patton system seems to carry to the extreme the posi- 
Before leaving a description of token economies, it will be instructive to discuss in some detail a token environment established at the Richmond State Hospital in Indiana.99 This particular system, although involving a population of civilly committed alcoholics rather than chronic psychotics, is particularly worthy of note because it suggests just how easily the Ayllon and Azrin token economy unodel can be extended to other clinical categories of patients. ${ }^{50}$

Prior to the inception of the token econonny, legally committed alcoholics at Richmond State were first admitted to the Receiving Unit, where they were provided with rest and medical care. Within one or two weeks the patient was usually assigned to an open ward, with a

tion often advocated by behaviorists that noncontingent rewards ought to be provided at an "adequate but relatively low level," with preferred reinforcers being available "contingent upon the occnrrence of desired response patterns." BANDURA, supra note 4 , at 231 . Under such an approach, therapy can be managed chiefly by positive reinforcement, without resort to punishment, and patients, the argument continues, have only themselves to blame if their privileges seem inadequate. Indeed, several programs have noted the benefits of an earn-your-way system, in notable contrast to more traditional approaches where "mandating educational or group therapy participation by threatening loss of visiting and other privileges or delayed release appeared to stimulate the social defiance and self-defeating traits of the population, and rebellion against the regulations of the institution provided an increase in prestige and enhanced status in the eyes of the peer group." Glicksman, Ottomanelb \& Cutler, The Earn-Your-Way Credit System: Use of a Token Economy in Narcotic Rehabilitation, 6 INT'L J. OF THE ADDICTIONs 525 (1971). Some commentators have criticized our peno-correctional system for giving inmates non-contingently whatever benefits may be available, and then denying some of the benefits as punishment for wrongful behavior-a system where "the staff members are cast in the unenviable role of punitive agents, and the [inmates] can move only in a downward direction," BANDURA 230. To the same effect, see Hindelang, A Learning Theory Analysis of the Correctional Process, 4 Issues IN CRminology 43, 44-45 (1969). See also M. Hindelang, Social Learning Theory and Social Problems: The Case of Prisons 9 (unpublished manuscript on file with author): "At the same time that a noncontingent system of rewards is operating a contingent system of punishments is attenpted; the result is that inmates come to view the rewards as rights rather than privileges and when they are threatened with the denial of those rewards they become justifiably embittered." (citations omitted). It has been suggested that when contingencies are so managed, "the majority of the participants coniply half-heartedly with the minimum demands of the institution in order to avoid penalties for any breach of the rules," and that, in a psychiatric setting, "patients can best maximize their rewards by nerely adopting a passive patient role." BandURA 230 . If the legal system wishes to accept the advice of the behaviorists, the crucial question for the law, of course, will be to define, for various clinical populations, just where the line of non-contingent rewards at an "adequate but relatively low level" ought to be drawn.

49. Narrol, Experimental Application of Reinforcement Principles to the Analysis and Treatment of Hospitalized Alcoholics, 28 Q. J. OF STUDIES ON ALCOHOL 105 (1967).

50. As will be apparent, it also raises certain serious questions about the ethical propriety of the type of psychological research involved. See also Rubin, Jokers Wild in the Lab, PsYcholOGY TODAY, Dec., 1970, at 18. 
work assignment within the hospital and all the available privileges. ${ }^{b 1}$ When the token system was introduced, certain alcoholic patients without intellectual, organic or psychotic impairments were inducted into the prograin. ${ }^{52}$ Work in the hospital labor force, compensated by points, was deemed the target behavior. The reinforcers included a broad range of patient needs and privileges:

The motivational power of the points was derived from allowing their exchange for every possible purchase within the hospital; thus, room and board, clothing maintenance, canteen purchases, Alcoholics Anonymous meetings, short leaves of absence, disulfiram treatment, different kinds of psychotherapy, and special instruction could all be freely selected, if paid for out of earnings..$^{53}$

Points were also needed to purchase advancement through the five tier system used at Richmond. The five tiers consisted of two closed wards, a semi-closed ward where ground privileges were available by purchase, and two open wards with pass privileges. Patients could purchase promotion only at weekly intervals.

The program was considered aversive by prospective members, ${ }^{64}$ as well as by the inducted nembers who requested weekly group meetings which became, mainly, "a grievance session centering around project rules." the fact that "a deprivation situation was established by starting patients in a closed ward of low status, substandard material and social comfort, and curtailed freedoin, relative to other wards in the hospital." The legal issues raised by the token economies may be apparent by now and they will be considered in the next section. An analytical examination of some of the more difficult competing psychological and legal considerations will, however, be deferred until section III.

51. Narrol, Experimental Application of Reinforcement Principles to the Analysis and Treatment of Hospitalized Alcoholics, 28 Q. J. OF STUDIES ON ALCOHOL 105, 107 (1967).

52. Id.

53. Id. at 108. With respect to the right to treatment, the same author states: "The obligation to treat the patient need not be neglected, since purchase of all the available therapeutic services may be permitted." Id. at 106-07.

54. Id. at 109.

55. Id.

56. Id. at 108. Of particular concern, from the viewpoint of the ethics of research, is that "work was made the target behavior for the purposes of simple demonstration of reinforcement technique." $1 d$. at 107-08. In other words, "the project had no therapeutic purpose, but demonstrated that behavior can be controlled in a simulated economy." Id. at 107. The study proved simply that project patients worked 8-hour days as opposed to the 4-hour days worked by non-project alcoholic patients. Id. at 109. But that is hardly a startling finding, particularly since the project was based on the Ayllon \& Azrin study, which had already established the point. Indeed, the author was himself hardly surprised by the outcoine: "Definite evidence of increased work output was obtained, as might be expected." Id. 


\section{II}

\section{LAW AND TOKEN ECONOMIES}

To speak at the moment of a specific "law of token economies" is of course out of the question, for at this date there is scarcely a handful of statutory and judicial pronouncements dealing even generally with the rights of the institutionalized mentally ill. Until very recently, the judicially manufactured "hands-off" doctrine enabled the courts to duck important questions regarding the limits of administrative discretion in the operation of prisons and mental institutions. ${ }^{57}$ Accordingly, the correctional and therapeutic establishments were in effect given, by default, the legal nod to manage their institutions-and to conduct their therapy ${ }^{58}$ - as they saw fit. But the last few years have witnessed a remarkable turnabout in the willingness of courts to scrutinize living conditions in total institutions. Though the activity has thus far been slower in the mental health area than it has been with regard to prisons, the successful legal penetration of inental hospitals appears to be a more promising prospect than in the analogous prison movement. Already, soine bold and far-reaching decisions have been rendered, ${ }^{59}$ and there is the further possibility of widespread legislative action. ${ }^{60}$ From the sparse legal precedents, one can detect a rather clear trend, and the emerging law bears rather directly on the rights of patients subjected to a token economy.

The encouragement of certain target responses-such as proper personal hygiene and self-care-surely seems beyond legal question, ${ }^{61}$ but it will be recalled that the principle target response of most token economies is adequate functioning on an institutional work assignment. Many persons both within and without the legal profession, however, find it objectionable in effect to require patients-especially involuntarily committed patients- to work for mental institutions, particularly without standard compensation. Though the work assignments are

57. E.g., Note, Beyond the Ken of Courts: A Critique of the Judicial Refusal to Review the Complaints of Convicts, 72 YALE L. J. 506 (1963).

58. E.g., N. Kuttrie, The Right to be Different: Deviance and Enforced Therapy 307-08 (1971). Cf. O'Donoghue v. Riggs, 73 Wash. 2d 814, 820 n.2, 440 P.2d 823, 828 n.2 (1968): "One who enters a hospital as a mentally ill person either as a voluntary or involuntary patient, impliedly consents to the use of such force as may be reasonably necessary to the proper care of the patient . . . "

59. Covington v. Harris, 491 F.2d 617 (D.C. Cir. 1969); Wyatt v. Stickney, 344 F. Supp. 373 (M.D. Ala. 1972) (Bryce and Searcy Hospitals).

60. E.g., CAL. Welf. \& INST'NS CODE $\$ 5325$ (West Supp. 1971).

61. Ironically, however, an experiment conducted by Ayllon and Azrin seeins to deinonstrate that "although the reinforcement for self-care was initiated to maintain a minimum standard of cleanliness and personal hygiene, changes in the reinforcement contingencies produced no appreciable difference in self-care practices," TOKEN ECONOMY, supra note 16, at 255. 
often cast in therapeutic terms, such as overcoming apathy and institutionalization, the critics view the jobs as simple laborsaving devices which exploit patients ${ }^{62}$ and, indeed, which soinetimes nake hospital retention of particular patients almost indispensable to the functioning of the institution. ${ }^{63}$

That patient job assignments are in fact often laborsaving is beyond question, as is the fact that work output will increase substantially when work is contingently reinforced by the standard reinforcers employed by token economies. Indeed, it will be recalled that at Anna State Hospital in Illinois, Ayllon and Azrin concluded that ward efficiency soared astronomically-fourfold ${ }^{64}$ - because of a token system involving job performance, and they noted further that unsatisfactory job performance resulted in administrative disruption. ${ }^{65}$ During a patient vacation period "the additional work required to keep the ward functioning . . . had to be made up by paid employees whose hours almost doubled." "Be

It seems clear that the law will not tolerate forced patient labor that is devoid of therapeutic purpose and which is required solely as a laborsaving technique. The Second Circuit, invoking a Thirteenth Amendment mvoluntary servitude rationale, so held in $1966 .{ }^{67}$ Simce then, recognition that there is not always a sharp line dividimg therapeutic and non-therapeutic assignments has led to varymg legal theories for dealing with —or for avoiding - the problem.

One rule is suggested by Bruce Ennis, a leading mental health lawyer who is keenly aware of the disparate per dien cost between private and state hospitalization and of the cost-saving devices resorted to by state hospitals. He would adopt the following as a legal rule of thumb in deciding whether work assignments have therapeutic value: "If a given type of labor is therapeutic, we would expect to find patients in private facilities performing that type of labor. Conversely, labor

62. E.g., Ennis, Civil Liberties and Mental Illness, 7 CRIM. L. Bull. 101, 122 23 (1971). At Anna State Hospital, because the token value of jobs is set by factors of supply and demand, "some jobs that were fairly demanding physically and that required about three hours through the day for completion, such as sweeping the floors, earned only about five tokens...." TOKEN ECONOMY 204.

63. ToKen ECONOMY, supra note 16, at 201.

64. Id. 188.

65. Id. at 201-02.

66. Id. at 210 .

67. Jobson v. Henne, 355 F.2d 129, 132 n.3 (2d Cir. 1966). The court also noted that if concededly involuntary labor is non-therapeutic, even compensation for the work will not necessarily satisfy Thirteenth Amendment reqnirements, for "the mere payment of a compensation, unless the receipt of the compensation imduces consent to the performance of the work, cannot serve to justify forced labor." Id. 
which is not generally performed in private facilities should be presumed . . . to be cost-saving rather than therapeutic." ${ }^{\prime 68}$

The "avoidance" approach is exemplified by the elaborate decision in Wyatt v. Stickney, ${ }^{69}$ in which the court barred all involuntary patient labor involving hospital operation and maintenance-whether therapeutic or not-but permitted voluntary institutional work of either a therapeutic or a non-therapeutic nature, so long as the labor is coinpensated pursuant to the federal minimum wage law. ${ }^{70}$ To insure the voluntary nature of any institutional work assignment undertaken, the Wyatt court specified further that "privileges or release from the hospital shall not be conditioned upon the perfornance of labor"71 involving hospital maintenance. ${ }^{72}$

The approach taken by the landmark Wyatt decision, if widely followed, would have an immense impact on traditional token economies. Patients could not be forced in any way to perform institutional labor assignments-and the force could not legitimately be exerted indirectly by making basic reinforcers "contingent" upon appropriate performance. Further, if patients should decide voluntarily to undertake institutional tasks, the minimum wage is the legally required "reinforcer." Under Wyatt, therapeutic assignments unrelated to hospital operations can constitute legitimate target responses that can be rewarded without regard to the minimum wage. But, perhaps most significant for token economies, Wyatt and related legal developments seem to have a great deal to say regarding the definition of legally acceptable reinforcers. Wyatt, together with an occasional piece of proposed $^{73}$ or enacted ${ }^{74}$ legislation, has begun the process of enumerating the rights guaranteed to hospitalized mental patients. The crux of the problem, from the viewpoint of behavior modification, is that the items

68. Ennis, Civil Liberties and Mental Illness, 7 CRIM. L. Bull. 101, 123 (1971) (emphasis in original).

69. Wyatt v. Stickney, 344 F. Supp. 373 (M.D. Ala. 1972) (Bryce and Searcy Hospitals).

70. Id. at 381. The minimum wage law is the Fair Labor Standards Act, 29 U.S.C. $\$ 206$ (1971). Judge Johnson in Wyatt further ordered that payment to patients for such work shall not be applied to offset hospitalization costs. Id. at 13.

71. 344 F. Supp. at 381.

72. Under Wyatt, the only type of work that can seemingly be "required," and the only type of work exempt from minimum wage coverage, is therapeutic work unrelated to hospital functionimg. Further, according to Wyatt, patients may also be required "to perform tasks of a personal housekeeping nature snch as the making of one's bed." Id.

73. Ralph Nader's Center for Study of Responsive Law has produced a suggested statute covering rights of committed patients. The proposal is reproduced in PsyCHIATRIC JUSTICE PROJECT, supta note 1, at 225-26.

74. E.g., The Ianterman-Petris-Short Act, CaL. WeLF. \& INST'NS CODE $§ 5325$ (West Supp. 1971). 
and activities that are emerging as absolute rights are the very same items and activities that the behavioral psychologists would employ as reinforcers-that is, as "contingent rights."

According to the Wyatt court, a residence unit with screens or curtains to imsure privacy, together with "a coinfortable bed, . . . a closet or locker for [the patient's] personal belongings, a chair, and a bedside table are all constitutionally required." ${ }^{5}$ Under Wyatt, patients are also insured nutritionally adequate meals with a diet that will provide "at a minimum the Recommended Daily Dietary Allowances as developed by the National Academy of Sciences." Wo Wyatt further enunciates a general right to have visitors, ${ }^{77}$ to attend religious services, ${ }^{78}$ to wear one's own clothes ${ }^{79}$ (or, for those without adequate clothes, to be provided with a selection of suitable clothing), and to have clothing laundered.80 With respect to recreation, Wyatt speaks of a right to exercise physically several times weekly and to be outdoors regularly and frequently, ${ }^{81}$ a right to interact with members of the other sex, ${ }^{82}$ and a right to have a television set in the day room. ${ }^{83}$ Finally, apparently borrowing from Judge Bazelon's opinion for the District of Columbia Circuit in Covington v. Harris, ${ }^{84}$ Judge Johnson in Wyatt recognized that "patients have a right to the least restrictive conditions necessary to achieve the purposes of commitment"s5 - presumably including, if clinically acceptable, ground privileges and an open ward.

Thus, the usual target behaviors for token economies would be disallowed and the usual reinforcers will be legally unavailable. The

75. Wyatt v. Stickney, 344 F. Supp. 373, 381-82 (M.D. Ala. 1972) (Bryce and Searcy Hospitals).

76. Id. at 383 .

77. Id. at 379. See also CAL. WeLF. \& INST'NS Cope $\S 5325(c)$ (West Supp. 1971).

78. 344 F. Supp. at 381.

79. Id. at 380. See also CAL. Welf. \& INST'NS Cope $\$ 5325(a)$ (West Supp. 1971).

80. 344 F. Supp. at 381 .

81. Id.

82. Id.

83. Id. at 382.

84. 419 F.2d 617 (D.C. Cir. 1969).

85. Wyatt v. Stickney, 344 F. Supp. 373, 379 (M.D. Ala. 1972) (Bryce and Searcy Hospitals). The "least restrictive alternative" or "less drastic means" rationale was first applied in the mental health law area in Lake v. Cameron, 364 F.2d 657 (D.C. Cir. 1966), an opinion authored by Judge Bazelon, which held that commitment itself should be ordered only if no suitable but less drastic alternatives to commitment could be located. For a discussion of the constitutional doetrine of "less drastic means" in the commitment context, see PsYchistric Justice ProJect, supra note 1, at 140-46. See also Chambers, Alternatives to Civil Commitment of the Mentally Ill: Practical Guides and Constitutional Imperatives, 70 MrCH. L. REv. 1107 (1972). In Covington v. Harris, 419 F.2d 617 (D.C. Cir. 1969), Judge Bazelon simply extended the doctrine to life within the confines of the hospital environment. 
emerging law appears to vindicate the assertions of the patients who, at the inception of the Patton State Hospital token econoiny, "pointed out to the nurses that the state had an obligation to feed thein and that the nurses were acting illegally in denying thein entrance to the dining rooin." ${ }^{\text {Co }}$ Chronic patients at Anna State Hospital who lad to work for screens and personal lockers to insure privacy would, under Wyatt, have those items provided noncontingently. According to the "Ieast restrictive conditions" rationale of Covington and Wyatt, it would seentingly be impermissible to house on closed wards those patients clinically capable of exercising ground privileges, such as Richmond State Hospital's admittedly non-psychotic alcoholic patients who, before the onset of the token econoiny program, would have quickly been placed on an open ward. ${ }^{87}$ The identical "least restrictive conditions" rationale would presumably also invalidate programs, such as the one at Anna State Hospital, ${ }^{88}$ in which ground privileges or supervised walks are available only by purchase, and programs in which outright release from the institution is conditioned upon the accumulation of a set nuniber of tokens or points. ${ }^{89}$

86. Schaefer, supra note 44 , at 29.

87. A similar problem seems to be present in the token economy system of State Hospital North, Orofino, Idaho, as described in Lloyd \& Abel, Performance on a Token Economy Psychiatric Ward: A Two Year Summary, 8 BeHAv. Res. \& THERAPY 1 (1970). In addition to using tokens for "standard" reinforcers, the State Hospital North program has a phase system which requires the accumulation of tokens for phase promotion. Group C, for example, is a closed ward, and promotion to Group B, which has ground privileges, requires earning 2,000 tokens in a three week period. Further, failure to earn substantial tokens while in Group B or A may result in demotion to Group C. Id. at 5. To the extent that certain Group $\mathrm{C}$ patients could clinically manage ground privileges-which, given the system, seems almost beyond doubt-this program and many others devised along similar patterns seem to offend the "less drastic means" test of Covington and Wyatt.

88. TOKEN ECONOMY, supra note 16, at 226. Ayllon and Azrin do not specify the percentage of patients on their ward clinically capable of exercising ground privileges, but Atthowe and Krasner, in their report on a token economy for chromic psychotics at the Palo Alto Veterans Administration Hospital, estimate that fully $40 \%$ of their patients could, without difficulty, leave the ward unescorted. Atthowe \& Krasner, Preliminary Report on the Application of Contingent Reinforcement Procedures (Token Economy) on a "Chronic" Psychiatric Ward, 73 J. of ABNoRmal PsycholOGY 37, 38 (1968). Any scheme that required such patients to purchase ground privileges would presumably run afoul of Covington and Wyatt.

89. A token economy program in New York which involves civilly committed narcotic addicts presumably hinges release-or at least eligibility for release consideration-upon the accumulation of 936 points. Glicksman, Ottomanelli \& Cutler, The Earn-Your-Way Credit System: Use of a Token Economy in Narcotic Rehabilitation, 6 INT'L J. OF THE ADDictions 525-27 (1971). To the extent that the point accunnulation system does not mesh squarely with statutory or clinical criteria for release, such a system presents serious questions regarding the unwarranted deprivation of liberty. The only saving grace for the described program seems to be that its patients are released after an average stay of 4 unonths, whereas committed addicts not on the earn-your-way token system are confined for an average of 7.5 months. Id. at 
Wyatt is obviously a decision of extraordinary detail and specification, perhaps because of comprehensive stipulation among the parties and amici. ${ }^{90}$ Nonetheless, the case ${ }^{91}$ is fully consistent with the trend of legal thought. ${ }^{92}$ Because the distinct direction of legal thinking

528. See also Atthowe, Ward 113 Program: Incentives and Costs-A Manual For Patients 5, 10 (Veterans Ad., Palo Alto 1964) (before patient can be eligible for 90day trial visit, must be in Group A for 30 days, and it costs 120 tokens to enter Group $A$, assuming there is an opening).

90. Wyatt v. Stickney, 344 F. Supp. 373, 375-76 (M.D. Ala. 1972) (Bryce and Searcy Hospitals).

91. Another, somewhat less precise, legal problem facing token economies may exist in the confusion between activities that constitute target responses and those that constitute reinforcers. More specifically, different token economies may classify the same activity differently. For example, chronic patients at the Palo Alto Veterans Administration Hospital earned tokens for attending group activities, recreational events, and movies (which were viewed as target behaviors), whereas Anna State Hospital patients had to expend tokens to attend similar activities (which were viewed as reinforcers). Compare Atthowe, supra note 89, at 7, with TOKEN ECONOMY, supra note 16, at 226. In view of the emerging constitutional right to treatment [see Wyatt v. Stickney, 325 F. Supp. 781 (M.D. Ala. 1971)], it seems problennatic at best to charge for psychotherapy sessions, as at Anna State Hospital and Richmond State Hospital, particularly when so few patients seem willing to expend tokens to attend such sessions. E.g., TOKEN EcoNoMY 66-67, 226, 234; Narrol, supra note 51, at 108-09. Indeed, even the previously mentioned activities-such as recreational events and movies - may have significant therapeutic value (and may fall within the scope of the right to treatment) in reducing boredom, increasing interaction and, in the case of movies, in providing a vicarious experience for learning or modeling appropriate social behavior. See BANDURA, supra note 4 , at 179-82.

It can be easily contended, therefore, that therapy sessions, recreational events, movies, writing materials (to increase contact with the world outside) and other items and events ought to be provided, as part and parcel of the right to treatment, on an absolute, noncontingent basis. Cf. Covington v. Harris, 419 F.2d 617, 625-26 (D.C. Cir. 1969). Interestingly, however, even the noncontingent ready availability of such therapeutic itens and events may be insufficient to arouse interest in them on the part of a highly apathetic patient population. A possible solution is to convert important therapeutic activities into token-earning target responses, as Atthowe did in Palo Alto. In psychological terms, such a course of action requires "considering the selection of a reinforcer as a response to be strengthened." Ayllon \& Azrin, Reinforcer Sampling: A Technique for Increasing the Behavior of Mental Patients, $1 \mathrm{~J}$. of Applied BeHAytor ANALYsis 13, 14 (1968). In legal terms, we seein to have developed a new category of "reinforced rights."

Those with Hohfeldian hangups might wish to construct a spectrum of patient rights-and correlative hospital obhigations-along the line of privileges (dispensed or withheld by hospital discretion), contingent rights (legitimate primary reinforcers mandatorily available by token purchase), rights (available absolutely and noncontingently), and reinforced rights (target responses which can be engaged in as a matter of right and which will be reinforced by tokens)!

92. E.g., Ennis, Civil Liberties and Mental lllness, 7 Crim. L. Burl. 101 (1971). See Cal. Welf. \& INST'Ns COde \& 5325 (West Supp. 1971). See also PsYchintric Justice Project, supra note 1, at 225-26 (draft legislation prepared by Center for Study of Responsive Law). The legislative developments occasionally cover ground not touched by Wyatt. The California statute, for example, gives patients the right "to have ready access to letter writing materials, including stamps ...", CAL. WELP. \& INST'NS CODE $\S 5325(\mathrm{e})$, and the statutory proposal of the Center for Study of 
bears so heavily on traditional tactics for the behavior modification of chromically psychotic behavior, it is important to examine closely certain particulars of the psycho-legal conflict and their implications and to point, if possible, to a proper path for future legal and therapeutic development.

\section{III}

\section{ANALYSIS AND IMPLICATIONS}

The important question of the therapeutic or non-therapeutic nature of institutional labor is unfortunately far more complex than would be indicated by the black or white treatment it has received from both legal and psychological quarters. For instance, Ennis's imitially attractive and easy-to-apply rule of thumb-that types of patient labor performed at public but not at private hospitals should be presumed costsaving rather than therapeutic ${ }^{33}$ - simply cannot withstand close scrutiny. Ennis's formula is undermined by the clinical and socio-economic differences between private and public hospital patients. Private hospital patients are typically skilled, of adequate ineans, and in the hospital for a short stay. Chronic psychotics at state institutions are almost mvariably persons who have been hospitalized and unemployed for long periods of time; they are overwhelmingly poor, unskilled, of advanced age, and likely to suffer considerable stigmatization upon release from the hospital. ${ }^{94}$

Given this characterization of chronic mental patients, combined of course with apathy, dependency, and institutionalization, ambitious employment opportunities for released chronics are virtually out of the question. ${ }^{95}$ Indeed, when viewed froin that perspective, together with the fact that work of almost any kind is probably superior to idleness

Responsive Law states, explicitly, that patients are "to be given adequate writing paper, pencils, envelopes and stamps." See Psychiatric Justice Project 225. Indeed, the failure of these detailed statutes to cover some of the more basic rightssuch as food and beds-must be attributed to an assumption on behalf of the draftsmen that such rights were beyond dispnte or beyond denial in practice.

93. Ennis, Civil Liberties and Mental Illness, 7 CrrM. L. Bull. 101, 123 (1971).

94. E.g., TOKEN ECONOMY, supra note 16, at 54; BANDURA, supra note 4, at 278. See also Lloyd \& Abel, Performance on a Token Economy Psychiatric Ward: A Two Year Summary, 8 BeHAv. Res. \& Therapy 1, 8 (1970); Spiegler, The Use of a School Model and Contingency Management in a Day Treatment Program for Psychiatric Outpatients 6 (paper presented at Rocky Mountain Psychological Association Convention, Denver, Colorado, May 1971).

95. E.g., G. Fairweather, D. Sanders, H. Maynard, D. Cressler, \& D. Bleck, COMMUNITY LIFE FOR THE MÉNTALLY Ill: AN ALternative to Institutional CARE 207 (1969) [hereinafter cited as COMMUNITY LIFE]. Indeed, the relapse rate for released chromics is so high and employment prospects are so dim that some commentators have questioned hospital release as an appropriate therapeutic goal. See Lloyd \& Abel, supra note 94, at 8. 
in offsetting apathy, a wide range of institutional work activities have both therapeutic value and realistically approximate future employment goals. For example, Ayllon and Azrin noted about their patients at Anna State Hospital:

Almost all of the patients in the programmed environment were from rural or lower-class communities. They were all females. Most were housewives prior to admission and presumably would continue to be so after discharge. Their advanced age and their limited formal education indicated that if they were to be employed, they could hold only non-skilled positions. The target behaviors for these individuals seemed, therefore, to be the various performances involved in housekeeping and in unskilled employment.96

Further evidence that the motivation behind establishing such target behaviors is indeed therapeutic rather than simply cost-saving can be gleaned from several facts and from examples where cost-saving was not in issue. One Veterans Administration program for discharged chronics, for instance, provides patients with token-earning formal classes in shopping, washing, ironing and mending clothing, and related tasks. ${ }^{97}$ Moreover, in one of the few reported imstances where released chromics managed to adjust successfully to a form of community life and to remain employed-George Fairweather's project where released patients lived and worked togther in a semiautonomous community lodge ${ }^{08}$ - the nature of the employment was perfectly consistent with training provided by standard imstitutional tasks.

When tine group of patients in Fairweather's project was about to leave the hospital for the community, for example, it originally planned on opening a restaurant, the bulk of positions to consist of "cook, assistant cook, dishwasher, busboys, waiters and cashier." Eventually, however, the men settled on janitorial work and gardening as their source of income, but even those jobs were performed inadequately ${ }^{100}$ until the men received specific training for the work. ${ }^{101}$ And in a successful project conducted by one of Fairweather's associates and patterned after that model, but involving both sexes of chronic patients, community employment followed a strikingly similar course: "Men worked at golf courses and other such places in teams doing gardening, landscaping, and groundskeeping work. The women worked in

96. TOKEN ECONOMY, supra note 16 , at 54 .

97. Spiegler, supra note 94 , at 4 .

98. Community Life. Cf. B. Pasamanick, F. Scarpitti \& S. Dinitz, Schizophrentcs in the Community: AN Experimental Study in the PRevention of HosPITALIZATION (1967).

99. COMMUNITY Life 46.

100. Id. at 5 .

101. Id. at $50-51,54$. 
groups at several nursing homes, as well as in motels and restaurants in the local area." 102

From these examples, it should be apparent that many forms of institutional labor, even though concededly cost-saving, prevent apathy and prepare patients for life, however marginal, ${ }^{103}$ on the outside. If the performance of therapeutic institutional labor by patients is to be encouraged, however, certain safeguards should perhaps be required to insure that no patient becomes indispensable to his supervisor, a possibility which might result in the patient's continuation on the job becoming more important to the staff than his welfare, his treatment, or even his discharge. Administrative precautions taken in the Anna State Hospital program may prove instructive as legal guidelines: Ayllon and Azrin imsisted upon periodic job rotation ${ }^{104}$ and, moreover, established a firn rule that "no patient was ever allowed to obtaim a position for which she alone was qualified." 105 Instead, "a position was established only when several patients were known to be capable of filling that position." 106

If, given certain safeguards, voluntary ${ }^{107}$ institutional labor by

102. Id. at 332. That cost-saving and therapeutic labor are uot necessarily mutually exclusive concepts was recognized iu Jobson v. Henne, 355 F.2d 129 (2d Cir. 1966). Note that the therapeutic or non-therapeutic nature of particular institutional work assignments may well vary among clinical groups. Just as those tasks may be therapeutic from the perspective of public hospital chronic patients but not for private liospital patieuts, see text accompanying note 97 supra, so too the work may be therapeutic for chronic state hospital patients but not necessarily for prisouers or, particularly, for juvenile delinquents-who seemingly need academic proficiency to achieve vocational success in their long lives ahead far more than they need training in jamitorial work. Cf. BANDURA, supra note 4, at 278 . In fact, the entire legal analysis of token economies should probably vary with different clinical populations. For instance, the law would probably view the privacy claim that a room-divider screen ought to be provided as an absolute right (rather than merely be available as a contingent reinforcer) far differeutly in the context of dormitory-style living for the adult mentally ill than in the context of a juvenile institution. But see Wyatt v. Stickney, 344 F. Supp. 387, 404 (M.D. Ala. 1972) (Partlow Hospital) (screens or curtains mandated in an institution for mentally retarded children and adults). Further, resort to certain reinforcers may be arguably necessary to encourage appropriate behavior among one clinical group, but be unnecessary to induce the target behavior among a different clinical category. Consider, in that connection, the Richmond State Hospital scheme of treating nonpsyclotic alcoholics in a manner very similar to the way other token economy programs treat chronic psychotics.

103. Cf. Community LIFE, supra note 95 , at 337 . In view of the traditionally astounding speedy relapse rates for the great majority of discharged chromic patients, BANDURA, supra gote 4 , at 269 , marginality in the outside community seems, at least for the near future, to be an acceptable goal.

104. TOKEN ECONOMY, supra note 16, at 202.

105. Id. at 201.

106. Id.

107. Truly voluntary work would assume, of course, that no basic rights-food, beds, ground privileges, privacy-were made contingent upon performance. 
chronic patients is to be encouraged, what of Wyatt's minimum wage niandate? Such a mandate, besides vitiating any cost-savmg benefits of patient performance, might cause serious complications. First, it will mevitably divert scarce legislative appropriations away from other hospital and therapeutic uses. Second, a minimum wage requirement may encourage the hospital-and indeed the encouragement may be compounded by union and community pressure-to fill its imstitutional positions with permanent outsiders imstead of with patients, perhaps leaving the patients to pursue less therapeutic activities. ${ }^{108}$ In other words, a minimum wage requirement may possibly result in greater expenditures for less effective therapy.

Thus, although compensating all mstitutional tasks with the mininuum wage appears to be an attractive goal, it is clear that several major problems might be created by that requirement. ${ }^{100}$ It is clear, too, that various safeguards short of the minimum wage can be invoked to prevent patient peonage, and that voluntary patient labor can probably be encouraged either by nionetary rewards somewhat below the minimum wage or by whatever other reinforcers satisfy the Wyatt test.

But im many respects the work and wage question is secondary to the question of legally acceptable and psychologically effective reinforcers. If adequate appropriations were available, if community residents did not threaten to displace patients in the institutional labor force, and if certaim other kinks could be ironed out, ${ }^{110}$ few objections would be raised to specifying the minimum wage as a legally required reinforcer for patient-performed hospital work assignments. Indeed, if nionetary rewards, whether of minimum wage proportions or not,

108. Activities are less therapeutic if the skills they train are not marketable in the outside community. There is no point in using the hospital setting to build up socially adaptive behaviors if one can expect that the environment the patient is placed in after release does not also reward those behaviors. See generally, TokEN ECONOMY, supra note 16, at 49-54.

109. Another possible difficulty with mandating a minimum wage is that it imposes an external force on the token economy and may upset the system's delicate economic balance, its incentive system, etc. Winkler, who has studied the economics of token economies, has concluded that token systems constitute subtle and intricate economic models which parallel remarkably the economic system of the outside world. Winkler, The Relevance of Economic Theory and Technology to Token Reinforcement Systems, 9 Behav. Res. \& Therapy 81 (1971). In the Ayllon and Azrin token economy, for example, the token values of the various positions were set by concepts of supply and demand. ToKen ECONOMY 204. A mimimum wage reinforcer for all hospital positions, even if appended to a token system with different numbers of tokens available for different assignments, would surely have a profound influence on the pre-existing incentive system. See also Kagel \& Winkler, Behavioral Economics: Areas of Cooperative Research Between Economics and Applied Behavioral Analysis, $5 \mathrm{~J}$. OF APpliEd BeHavior ANalysis 335 (1972).

110. Such as the impact of a minimum wage requirement on the economic incentive system of the hospital. See discussion in note 109 supra. 
were sufficient to induce patient work performance, that would be a small price to pay to strengthen target behaviors.

The major problem faced by the token economy is the current trend towards expansion of the category of protected inmate interests. The law, relying on concepts such as freedom and dignity, would require, for example, that all patients be accorded minimal levels of privacy and comfort. To the behavioral psychologist, who operates from the premise of determinisin, philosophical notions of "freedom" and "dignity" are irrelevant. ${ }^{111}$ Rather, the psychologist views privacy or comfort as no more than useful tools which he can manipulate to make a psychotic's behavior more appropriate and socially adaptive-a goal which presumably all agree is in the best interest of both the patient and the society. In the psychologist's view it would surely be an ironic tragedy if, in the nanie of an illusory ideal such as freedom, the law were to deny the therapist the only effective tools he has to restore the chronic psychotic to his health-and his place in the community.

Wyat thus poses a painful dilemma. The behavior modifier suggests that chromic psychotics respond initially to only the most primitive reinforcers, and, therefore, only their contingent availability can n1otivate development of socially adaptive behavior. ${ }^{112}$ It follows, the behaviorists claim, that if the basics are made freely available as rights rather than as reinforcers, chronic psychotics may be destined to spend their lives functioning poorly in an institutional setting, whereas if those basic rights are converted into contingent reinforcers, there may be a real prospect of clinical improvement and discharge. ${ }^{113}$

If the empirical evidence supported the claim that token economies relying on primitive reinforcers worked very well with chronic patients-that, for example, virtually all patients improved dramatically and were able to earn the reinforcers required for a decent existence or if the evidence demonstrated that no less drastic means could

111. See B. F. SkinNer, BEyond Freedom And Dignity (1971).

112. E.g., BANDURA 227; TOKEN ECONOMY 269.

113. At first blush, the behaviorist position seems to clash with the data provided by J. K. Wing, who found that the clinical states of of schizophrenic patients at three different hospitals correlated closely-and positively-with the respective hospital policies on patent rights and liberty. Wing, Evaluating Community Care for Schizophrenic Patients in the United Kingdom, in CoMmUNTTY Psychitrit 138, 147-57 (Anchor ed., L. Roberts, S. Halleck \& M. Loeb, eds. 1969). Wing's analysis may possibly be reconciled with the behaviorist contention. First, it is not entirely clear from Wing's study that patients were assigned to the three hospitals on a random basis, and if they were not, a causal connection between patient rights and clinical states could not conclusively be inferred. And even if it could, the connection could well be limited to instances where contingency nuanagement systems are absent. In other words, it may be that it is far more therapeutic to provide patients with certain privileges absolutely than it is to deny then those privileges absolutely, but that it is better still to provide the privileges on a contingent basis. 
accomplish similar results-a re-evaluation of the emerging law might very well be in order. But a review of the pertinent literature suggests that behavior modification proponents inay have difficulty sustaining a burden of proof with respect to those matters.

First of all, while most token economy outcome studies report favorable results, ${ }^{114}$ the successes are far from overwhelming. Even in a project as dramatic as the Anna State Hospital study, eight of the 44 subject patients were basically unresponsive to the program, ${ }^{115}$ and success for the remaining patients was measured solely by their work output. $^{116}$ When judged by release data rather than by measures of work output, decreased apathy, ${ }^{117}$ or improved clinical state, ${ }^{118}$ results of token econoiny systems with chronic psychotics have not been encouraging. Even in the Atthowe and Krasner project at the Palo Alto Veterans Administration Hospital, which reported a doubling of the discharge rate, 11 of the 24 released patients returned to the hospital within 9 months, ${ }^{119}$ a more rapid relapse than is normally found in studies of chronic patients. ${ }^{120}$

We must also consider whether the results achieved by token economies-whatever they may be-could be matched or surpassed by less drastic nieans. ${ }^{121}$ Information is wanting, perhaps in part because be-

114. See, e.g., Gripp \& Magaro, A Token Economy Program Evaluation With Untreated Control Ward Comparisons, 9 BeHAV. Res. \& Therapy 137 (1971) (summarizing results achieved by other researchers).

115. ToKen Economy, supra note 16, at 269. See also Lloyd \& Abel, Performance on a Token Economy Psychiatric Ward: A Two Year Summary, 8 BeHAv. REs. \& THERAPY 1,7 (1970) (at least 10 of 52 patients remained predominantly in the lowest group, which was a closed ward, throughout the course of the study).

116. Even the drastic deprivations at Patton State did not produce spectacular results. Schaefer, supra note 44 , at 32 . Schaefer did, however, claim some spectacular results in an individualized positive reinforcement program, where a behavior modificatiou plan is tailored to each patient's particular problems. Id. at 33-36. Individualization will be discussed further in text infra.

117. Schaefer \& Martin, Behavioral Therapy for "Apathy" of Hospitalized Schizophrenics, 19 PsYCHOLOGICAL REPORTS 1147 (1966).

118. Gripp \& Magaro, supra note 114.

119. Atthowe \& Krasner, Preliminary Report on the Application of Contingent Reinforcement Procedures (Token Economy) on a "Chronic" Psychiatric Ward, $73 \mathrm{~J}$. ABNoRmal Psych. 37, 40 (1968).

120. "Results based ou follow-up studies disclose that approximately 70 percent of chromic patients who are discharged from mental hospitals return within 18 months regardless of the type of treatment received during the period of hospitalization." BANDIRA, supra note 4, at 269.

121. In fact, token economy programs differ considerably among themselves with regard to the nature of deprivations and contingent reinforcers resorted to. For instance, food and beds were subject to purchase at Patton State Hospital but were noncontingently available at Anna State Hospital. Further, patients in certain programs are able to earn tokens for engaging in activities which would cost tokens in other programs. See discussion in note 91, supra. Unfortunately, however, because reports of token economy programs are ofteu inadequate in their description of reinforcers, 
havior modifiers have not employed reinforcers other than the basics in standard use. It may be, for example, that creative observation of patient behavior preferences would reveal frequent behavior patterns, other than basic behaviors, which could be utilized as reinforcers. Also, although it is an impure technique according to orthodox behaviorism, another practical approach is simply to ask the patients what they would like to possess or to do. ${ }^{122}$

By exploring creatively for reinforcers, it is likely that therapists could construct a list of idiosyncratic objects and activities-mail order catalogue items, ${ }^{123}$ soft-boiled rather than standard hard-boiled eggs, ${ }^{124}$ and feeding kittens ${ }^{125}$ are actual clinical examples-that could be made available contingently im order to strengthen appropriate target responses. Moreover, to the extent that effective reinforcers are in fact idiosyncratic, it follows almost by definition that their contingent availability could not conflict with the legally emerging absolute general rights of patients.

A system of positive behavior modification based heavily on idiosyncratic reinforcers might be clinically as well as legally superior. Psychologists employing such systems ${ }^{126}$ have been able to devise individual treatment plans assuring each patient independent diagnostic and therapeutic attention. ${ }^{127}$

But individualized treatment plans, required by Wyat $^{128}$ and per-

and because they often measure success according to different criteria, inferences of comparative efficacy are difficult to draw, leaving our knowledge rather incomplete with respect to the therapeutic necessity of resorting to the more drastic reinforcers,

122. This technique is "impure" because, unlike the Premack principle, it relies on verbal expressions of intention to ascertain preferred beliavior, and the match is not always a perfect one. Ayllon and Azrin resorted to the technique to a limited extent. TOKEN ECONOMY 67-72. To help insure that a patient will refrain from reqnesting items that he does not in fact deeply desire, a down payment of a specified number of tokens can be required at the time of the request. Id. at 71-72.

123. TOKEN ECONOMY, supra note 16, at 69.

124. Id. at 68.

125. Atthowe \& Krasner, supra note 119, at 38.

126. E.g., Scliaefer, supra note 44, at 33-36 (Patton State Hospital individualized behavior modification program far more spectacnlar than its general token economy program); Spiegler, supra note 94.

127. In the Patton State Hospital program, individnalized problem areas included eating problems, grooming habits, and lallucinatory behavior. Scliaefer, supra note 44, at 33-36. Note that under an individualized program, it wonld not be unusual to have "some people paying while others are paid to play table games. . .." Spiegler, supra note 94 , at 8 . Such an individualized approach may solve the legal problem posed by the fact that some token "economies treat as reinforcers activities which others treat as target responses. See discussion of the problem in note 91 supra. Cf. TOKEN ECONOMY 10-11 (visitors, ground privileges, recreational activities not desired by certain chronic patients).

128. Wyatt v. Stickney, 344 F. Supp. 373, 384 (M.D. Ala. 1972) (Bryce and Searcy Hospitals). 
haps part of the einerging right to treatment, ${ }^{129}$ are not incoinpatible with the operation of ward-wide or hospital-wide general treatment systems designed to overcoine general patient problems such as indecisiveness, dependency, or apathy. In fact, the inost fruitful coinbination might be to combine individualized treatment programs with an efficient, easy-to-administer general therapeutic system. ${ }^{130}$ If, however, the criteria for a successful system is efficacy with the least drastic deprivations possible, it appears that token economies for chronic psychotics may well fimish no better than second best. ${ }^{131}$

Specifically, although it may not be determinative, the work of George Fairweather is highly relevant here. ${ }^{132}$ Though he speaks the language of social psychology and of small group theory rather than the language of behaviorism and learning theory, Fairweather relies in part on principles of behavior modification, and his work is discussed prominently in texts on that subjcct. ${ }^{133}$ But his study was bottoined on the behef that chronics, to survive outside, inust acquire problem-solving and dccision-making skills, and on the knowledge that small cohesive groups can effectively control the behavior of their ineinbers. ${ }^{134}$ Patients were divided into small task groups with monetary and pass privileges awarded according to the level of responsibility each individual attained. The money privileges for the most part came from personal funds of the patients who participated in the programs. The amounts of money and number of passes were set up in advance for each of four progressive levels of achievement. The task group as a unit becaune responsible for the progress of its individual niembers through the four desiguated steps. Step one involved personal care, punctuality on assignments, and cooperation in the orientation of new

129. E.g., Birnbaum, The Right to Treatment, 46 A.B.A.J. 499 (1960); Rouse v. Cameron, 373 F.2d 451 (D.C. Cir. 1966).

130. See Davison, Appraisal of Behavior Modification Techniques with Adults in Institutional Settings, in BeHAvior TherApy: Appraisal and STATUs 257 (C. Frnaks ed. 1969); Atthowe \& Krasner, supra note 119, at 41.

131. The einpirical evidence is convincing. See Community LIFE, supra note 95; Social Psychology in Treating Mental Illness: An Experimental Approach (G. Fairweather ed. 1964) [hereinafter cited as Social. Psychology].

132. See references in note 131 supra.

133. E.g., BANDURA, supra note 4, at 269-71, 275-78.

134. In this connection, Bandura cites an interesting unpublished report where the researchers "studied the amount of disruptive classroom behavior displayed by a child in the absence of any special reinforcenent and during subsequent periods when either she alone earned five points, or she and her immediate peers each earned one point for her commendable beliavior. It is interesting to note that the child's activities were more effectively controlled under the peer contingency even though it produced only one-fifth of the amonnt of reinforceinent provided on the individual basis. Apparently, through the group reward, change agents were able to cnlist the peers' aid in modifying the beliavior of their companion." BANDURA 281 . 
members. Step two required, in addition, acceptable work on the job assignment. Requirements in step three were individualized, with patients responsible for recommendimg the level of their own rewards. In step four the patient had responsibility for his departure plans, and had unlimited rights to withdrawal of money and passes. In step one the patient received ten dollars and a one day pass each week; in step two he received fifteen dollars per week and an overnight pass every other week. ${ }^{135}$

The task group was responsible for dealing with patient problems and for recommending to the staff the level of pass and monetary privileges deserved by each patient member. Patient task group recommendations were considered weekly by a staff committee. ${ }^{136}$ To establish cohesive and well-functioning groups, Fairweather would at times advance or demote the group as a unit. ${ }^{137}$

Fairweather found that over time pride in group achievement appeared to become a more important motivator than money or passes. ${ }^{138}$ Leaders emerged in the chronic psychotic groups as well as in other clinical categories, ${ }^{139}$ and the program was a therapeutic success: As compared with a control group subjected to traditional hospital therapy (not a token economy), the small group patients showed significantly less pathological behavior, ${ }^{140}$ greater social interaction, ${ }^{141}$ and greater participation during meetings. ${ }^{142}$ Moreover, the small group program

135. Social Psxchology 30. Fairweather's project was conducted at a Veterans Administration Hospital, and the patients were presumably drawing psychiatric disability benefits, which is where the inonetary rewards utilized in the experiment came from. Note, however, that even if this money were provided by the hospital, rather than from the patients' own sources, the total expenditure would probably be far less than if the patient labor were mandatorily compensated by the minimum wage. For comments on the possible disincentives to recovery provided by disability compensation-surely a fruitful topic for psycho-legal investigation-see Spiegler, supra note 94, at 6; Davison, supra note 130, at 257.

136. Social Psychology, supra note 31, at 40-41. The staff cominittee could of course amend or reject the suggestions. Id.

137. Id. at 173 .

138. Id. at 189.

139. Id. at 181,283 . The patients in Fairweather's study constituted a heterogeneous population and varied considerably in degree of chronicity, but the various task groups surely had their share of chronic psychotics. Id. at 33. And Fairweather's follow-up cominunity adjustment project involved almost exclusively chronic patients. CoMmunity LIFE, supra note 95, at 32, 238. It seems, then, that a comment made by Davison that Fairweather's study did not involve chronic psychotics, is simply erroneous. Davison, supra note 130, at 257. As an aside, it should be noted that Fairweather's study of heterogeneous groups yielded fascinating findings regarding the ideal chnical mixture required in small groups to produce first-rate decision-making. Social PsYCHOLOGX, supra note 131, at 193, 209.

140. Soctal PsychologX, supra note 131, at 61.

141. Id. at $70,283$.

142. Id. at 89 . 
substantially reduced hospitalization. ${ }^{143}$ When combined with an aftercare program involving a voluntary living arrangement in a semiautonomous (and eventually autonomous) community lodge, the Fairweather system achieved the long-awaited goal of adequate employment and community adjustment for discharged chronic psychotics. ${ }^{144}$ Fairweather thus produced impressive results with chronic psychotics im an environment clearly "less drastic" in deprivation than any of the traditional token economies. Obviously, Fairweather's patients were provided with food and beds. Further, the ward was open and patients had complete access to the hospital grounds. ${ }^{145}$ The ward was equipped with a television set, table games, nuagazines and the like, ${ }^{140}$ and freely available activities included library reading, movies, dances and bowling. ${ }^{14 \pi}$

Most of these privileges were available ouly by purchase in the token economy programs. Yet a patient at the bottom of Fairweather's hierarchy was provided, without a work assignment, not only with these privileges, but also with ten dollars and a one day pass each week. Indeed, life at the lowest level of Fairweather's ladder compares favorably with the conditions at advanced levels in some token systems. ${ }^{148}$

Fairweather's approach, then, seems preferable to token economies on several counts. First and foremost, his small group system has yielded impressive results which are unmatched by token systems. Second, while token systems deprive patients of basic comforts in their rehance on primitive reinforcers, Fairweather employs only money and

143. Id. at 168.

144. COMMUNITY LIFE. When unaccompanied by a cohesive-group aftercare arrangement, however, chromic patients who had participated in the small group program prior to discharge had a high relapse rate, as do chronics generally. SocinL PsYCHOLOGY 168.

145. Social Psychology 32.

146. Id. at 46.

147. Id. at 153. It is not clear whether Fairweather's patients were provided with such items as screens or personal lockers, but it is clear that those items were either available or unavailable noncontingently; that is, it is not the case, as was true at Anna State Hospital, that they were available only to those able to purchase them. Because Fairweather did not employ those items as reinforcers, his therapeutic system would seemingly be unaffected by a requirement, such as enunciated in Wyatt, that all patients be given those items as a matter of absolute right.

148. E.g., Bruce, Tokens for Recovery, 66 AM. J. Nursing 1799, 1802 (1966) (discussing conditions for the "middle group" at Patton State Hospital); Lloyd \& Abel, Performance on a Token Economy Psychiatric Ward: A Two Year Summary, 8 BeHAv. RES. \& TherAPY 1, 5 (1970) (discussing conditions for "Group B" at Idaho's State Hospital North); Narrol, Experimental Application of Reinforcement Principles to the Analysis and Treatment of Hospitalized Alcoholics, 28 Q. J. OF STUdies ON AlcoHoL 105, 108 (1967) (discussing steps 3 and 4 at Richmond State Hospital). See also text accompanying notes 52-54 supra. 
passes. ${ }^{140}$ Third, Fairweather's approach is thoroughly oriented toward release and community adjustment, and he recognizes that once cohesive groups have been formed in the hospital, "an immediate inove to the community is essential."150 Finally, Fairweather's behavior modification model emphasizes the development of confidence and decision-1naking ability rather than performance of assignments. For whatever it is worth, Fairweather's system may be ethically or at least emotionally more palatable than the manipulative techniques of the token economies.

\section{CONCLUSION}

Fairweather's small group model, with its rich results and rather minor deprivations, poses a serious threat to token economies. If further studies continue to indicate that, except in extreme circumstances, token economies for chronic psychotics resort to more drastic deprivations than other therapies without producing better results, ${ }^{151}$ it is likely

149. Fairweather's contingent pass device may pose a question in light of the requirement of Covington v. Harris, 419 F.2d 617 (D.C. Cir. 1969), that patients be provided with as much liberty as is clinically appropriate. But the fact that even lowest level patients are entitled in the Fairweather system to one day pass per week may alleviate Covington objections, especially if the contingent availability of passes above and beyond one per week are shown empirically to constitute powerful motivators. But whatever Covington problem may exist could, of course, be vitiated entirely if monetary rewards alone were found to be sufficient reinforcers, as future research might indeed show.

150. Social Psychology, supra note 131, at 9.

151. One possible exception is the most extremely regressed cases who fail under all other techniques. Even under Fairweather's system, for example, it is probably true, as he admits, Social Psychology 172, that some patients may be unresponsive, and it is certainly possible that, for those patients, idiosyncratic reinforcers will be undiscoverable or unworkable. For them, the fields of law and psychology must face the issue whether, in the hopes of therapeutic success, basic and primitive items and activities should be used as reinforcers. If the answer is affirmative, certain safeguards should be built into the legal structure to insure that decisions to invoke the traditional token economy model are made only after full consideration and only in rare instances. For example, demoustrated ineffectiveness of the Fairweather and idiosyncratic systemis could be a legal prerequisite to rehance on the traditional token technique. Such an approach, which may create an additional incentive for patients to succeed within the Fairweather scheme and accordingly avoid the more distasteful ordeal of a standard token system, would insure that basic rights are not converted to contingent reinforcers for the bulk of chronic psychotics for wholn that appears unnecessary and, a fortiori, for other clinical categories, such as juvenile delinquents and non-psychotic alcoholics, who presumably can be notivated by non-primitive reinforcers which fall without the prohibitions of Wyatt and related legal mandates. In effect, if reliance on reinforcers falling below the Wyatt-type baseline are to be resorted to, such a drastic scheme of positive token reinforcement should be properly deemed "aversive" for legal purposes and should follow, as closely as possible, emerging legal restrictions on aversive therapy. Hopefully, one such restriction will be the "less drastic means" rationale. Cf. BANDURA, supra note 4, at 551 (complaining that "exceedingly noxious procedures are occasionally employed even though they pro- 
that token systems will soon find themselves subject to both legal and behavioral extinction.

Indeed, if the law's general direction in the patient rights area proceeds uninterrupted, token economies may well become legally unavailable even if they are therapeutically superior to other approaches. That is because the developing law is creating new patient rights unaware that these rights will undermine a basic behavior modification technique. On the other hand, the behavior modifiers seem busy constructing token cconomies unaware that legal developments may soon call for their demolition.

Forcing these disparate disciplines to take note of each other-ob-

duce no greater changes than stimuli in much weaker intensities"); Schwitzgebel, supra note 2, at 279 (alcoholics have been treated with drastic drugs causing respiratory arrest, even though "[t]he results . . . are not clearly better than with emetics."). A requirement of informed consent is also emerging in the aversive therapy area, [e.g., Wyatt v. Stickney, 344 F. Supp. 373, 380 (M.D. Ala. 1972) (Bryce and Searcy Hospital)], but that requirement may have an awkward application in the token economy area: it is easy to imagine homosexual or alcohohic patients consenting to aversive techniques in hopes of securing desired behavioral improvement, but it is far more difficult to imagine an apathetic long-term patient, almost by definition unconcerned about his clinical state and his future, voluntarily consenting to forego the standard benefits of hospital life in favor of treatment under which those benefits would be available only by purchase. Surely, even if informed consent were given by such a patient, it might soon be revoked. Cf. Ex parte Lloyd, 13 F. Supp. 1005 (E.D. Ky. 1936) (addict who volunteered for treatment and contracted to remain in hospital for specificd time period but later changed his mind could not be compelled to remain hospitalized for the specified period); contra, Oretga v. Rasor, 291 F. Supp. 748 (S.D. Fla. 1968). Arguably, informed consent in a token economy setting could be replaced by an alternative protective device, such as the informed approval of a judicially selected human rights commitee chosen froin outside the hospital. See, e.g., Wyatt v. Stickney, 344 F. Supp. 387, 400 (M.D. Ala. 1972) (Partlow Hospital) (requirement that aversive behavior modification programs involving the inentally retarded "shall be reviewed and approved by the imstitution's Human Rights Committee and shall be conducted only with the express and informed consent of the affected resident, if the resident is able to give such consent, and of his guardian or next of kin, after opportunities for consultation with independent specialists and with legal counsel"). Further, a time limit should probably be set on the length of time the token procedure conld be invoked, with provision for a return to the noncontingent availability of basic benefits for patients seemingly unresponsive to even the token system. But clear-cut answers on the extent to which traditional token economies should be treated legally as an aversive technique must await further development in the law of aversive therapy itself-an area which, as noted in the Introduction to this Article, is receiving an ever-increasing amount of attention from the courts and the commentators. The use of aversive techniques raises squarely one of the perennial problems of law and research: society will obviously want to forbid aversive practices unless they have been demonstrated to be efficacious, but research-rather than legal prohibition -is needed to demonstrate whether the practices are in fact efficacious. To the extent that many aversive therapies are obviously experimental in nature, the emerging legal and ethical restrictions regarding experimentation with human subjects ought to be pertinent in devising a balanced but protective regulatory framework for their application. See generally Experimentation With Human Subjects (P. Freund ed. 1970); J. KATZ, EXPERMMENTATION WITH HUMAN BEINGS (1972). 
viously the principle object of this Article-should be helpful to both of them. Behavior modification proponents, convinced of the therapeutic indispensability of token economies for chronic patients, may have reservations about the Fairweather model. But unless systematic comparative studies of alternative therapies are performed soon, ${ }^{152}$ the law will be unable to incorporate the results in developing a sensible package of patient rights, and expected legal developments may ultimately preclude such studies.

152. The desirability of such studies has been repeatedly noted. See, e.g., BANDURA, supra note 4 , at 274. 